\title{
Guest editorial: Ruminant physiology; digestion, metabolism and effects of nutrition on reproduction and welfare
}

\author{
Y. Chilliard ${ }^{1 \dagger}$, M. Doreau ${ }^{1}$, I. Veissier ${ }^{1}$ and F. Bocquier ${ }^{2}$ \\ ${ }^{1}$ INRA, UR Herbivores 1213, Theix, F-63122 Saint-Genès-Champanelle, France; ${ }^{2}$ SupAgro-INRA, UMR 868 Élevage des Ruminants en Régions Chaudes, \\ 2 Place Pierre VIALA, F-34 060 Montpellier Cedex 1, France
}

The XI International Symposium on Ruminant Physiology (ISRP2009) was held in Clermont-Ferrand, France, from 6 to 9 September 2009. The previous meetings were held in Nottingham, UK (1960), Ames, USA (1965), Cambridge, UK (1969), Sydney, Australia (1974), Clermont-Ferrand, France (1979), Banff, Canada (1984), Sendai, Japan (1989), Willingen, Germany (1994), Pretoria, South Africa (1999) and Copenhagen, Denmark (2004) ${ }^{1}$. More than 500 scientists from 48 countries attended the ISRP2009.

As in previous ISRP meetings, the programme covered a wide range of topics. The ultimate goal of the symposium was to provide a comprehensive view of current knowledge and to draw perspectives on ruminant physiology to improve animal production efficiency, meat and milk quality, animal welfare and health and to limit environmental impact (greenhouse gases emission, nitrogen wasting), all these issues being in line with the current challenges for sustainable animal rearing in a changing world with new constraints and goals for animal production. The approaches proposed to address these challenges were very diverse, including the development of physiological approaches, molecular high throughput technologies and modelling, in order to unravel the mechanisms involved in digestion, metabolism and the interactions between nutrition, reproduction and welfare.

The programme of the symposium included 21 invited conferences that addressed ruminant comparative physiology, the rumen ecosystem and metagenomics, nutrient digestion and absorption, methanogenesis, tissue metabolism and gene expression, pregnancy, lactation and growth, adaptation to heat stress, nitrogen use, nutrition and reproduction, nutrition and welfare and nutrition for a sustainable ruminant production. Nineteen full papers of these conferences are published in the present special issue of Animal. The whole ISRP2009 programme also included 373 short (two pages) communications that have been published in a dedicated book (Chilliard et al., 2009).

We thank the scientific and organising committees of ISRP2009 and hope that the present special issue of Animal will be a tool and an inspiration for future progress in the field of ruminant nutrition and physiology. We express our warm thanks to the many contributors in the process ${ }^{2}$, especially to the organising committee members and to all scientists and technicians of the INRA Clermont-Ferrand/ Theix Research Centre, who made the symposium a large success; to the editing committees, whose expertise was essential for the publication of the scientific contributions; and to our sponsors.

\section{References}

Chilliard Y, Glasser F, Faulconnier Y, Bocquier F, Veissier I and Doreau M 2009. Ruminant physiology: digestion, metabolism, and effects of nutrition on reproduction and welfare. Proceedings of the XIth International Symposium on Ruminant Physiology, Clermont-Ferrand, France, September 6-9, 2009, 864 pp. Wageningen Academic Publishers, The Netherlands. http://www. WageningenAcademic.com/ruminant09.

Sejrsen K, Hvelplund T and Nielsen MO 2006. Ruminant physiology: digestion, metabolism and impact of nutrition on gene expression, immunology and stress. Proceedings of the Xth International Symposium on Ruminant Physiology, Copenhagen, Denmark, August 30-September 4, 2004, 600 pp. Wageningen Academic Publishers, The Netherlands.

\footnotetext{
${ }^{\dagger}$ E-mail: yves.chilliard@clermont.inra.fr

${ }^{1}$ For ISRP2004, the conference's papers were published in a dedicated book: Sejrsen et al. (2006) and the short communications were published in a special issue of Journal of Animal and Feed Sciences (Vol. 13, Supplement 1, 2004).
}

\footnotetext{
${ }^{2}$ With special thanks to F. Glasser, Secretary General of the symposium. See https://colloque2.inra.fr/isrp_2009_eng/ for details on the main contributors.
} 